\title{
EFFECT OF FEEDING DIETS SUPPLEMENTED WITH ZINC, COPPER AND SELENIM PRE OR POSTPARTUM ON MILK YIELD AND SOMATIC CELL COUNT OF FRIESIAN COWS
}

\author{
A.M.A. Salama, M.A. Abu El-Hamd, M.S. Sayah and S.A. Ibrahim \\ Animal Production Research Institute, Agricultural Research Center, Dokki, Egypt
}

\section{SUMMARY}

The objective of this study was to evaluate the effects of adding $\mathrm{Zn}, \mathrm{Cu}$ and Sein the ration of dairy cows on milk yield, somatic cell count (SCC) and blood parameters. A total of 39 Friesian cows between the $1^{\text {st }}$ and $3^{\text {rd }}$ parity and average live body weight $(\mathrm{LBW})$ of $532.7 \pm 23.5 \mathrm{~kg}$ were divided into three similar groups ( $n=13$ each) Mutiparous cows ( $n=10$ in each group) were divided according to their $B W$, parity and milk production of the previous season, while primiparous cows $(n=3$ in each group) were allotted based only on their BW. Cows of the $1^{\text {st }}$ group (G1) were fed concentrate feed mixture (CFM), rice straw and corn silage (control). Cows of the $2^{\text {nd }}$ group (G2) received $60 \mathrm{mg} \mathrm{Zn,} 20 \mathrm{mg} \mathrm{Cu}$ and $0.3 \mathrm{mg} \mathrm{Se} / \mathrm{kg}$ diet at 30 day pre-partum to calving, while those of the $3^{\text {rd }}$ group (G3) received the same dose of (G2) but from day one to 60 days of postpartum in the ration. Throughout the experimental period, cows were machine milked and daily milk yield was individually recorded for the $1^{\text {st }}$ four months. Milk composition, blood samples and lymphocytes, monocytes and granulocytes (immune response) were determined. Milk samples for $S C C$ determination were collected biweekly from 10 days after lactation until 90 days of lactation. Results revealed that $\mathrm{Zn}, \mathrm{Cu}$ and Se diet improved $(P<0.05)$ daily milk production of $G 2$ and $G 3$ by 22.7 and $12.0 \%$, respectively compared with $G 1$. G3 had higher $(P<0.05)$ percentages of fat, protein and lactose as compared to G1. G2 had higher $(P<0.05)$ percentages of fat and lactose compared to $G 1$, while protein percentage was similar to G1. Diet supplemented with $\mathrm{Zn}, \mathrm{Cu}$ and $\mathrm{Se}$ (G2 and G3) showed lower $(P<0.05)$ somatic cell count in milk as compared to G1. Increase SCC lead to decrease milk yield, fat, protein and lactose percentages. Cows of treatments $G 2$ and G3 were higher in red blood cell (RBC) and white blood cell (WBC) counts, hemoglobin $(\mathrm{Hb})$ concentration and haematocrit percentage (HCT, \%) than those of the control group. Cows treatment were higher significantly lymphocytes and significantly lower moncytes than control group. All protein fraction and Se concentrations were higher in G3 and G2 than in control group (G1), however, significantly higher in $G 3$ than in G2. But, plasma $\mathrm{Zn}$ and $\mathrm{Cu}$ concentration were higher significantly $(P<0.05)$ in $G 2$ and $G 3$ than the control group $(G 1)$.

Keywords: Friesian, lactation, somatic cell count, milk yield and trace minerals.

\section{INTRODUCTION}

Trace elements such as Manganese $(\mathrm{Mn})$, Copper $(\mathrm{Cu})$, Iron (Fe), Iodine (I), Selenium (Se) and Zinc ( $\mathrm{Zn})$, are essential in animal nutrition and are needed in very small amounts for essential metabolic reactions in the body. Their deficiencies are

Issued by The Egyptian Society of Animal Production 
often associated with alterations in many metabolic processes and cause various kinds of diseases. Deficiency of these trace elements causes severe economic loss due to increased susceptibility to oxidative stress, growth retardation in young animals, anemia (Bureau et al., 2008), decrease in feed efficiency and fertility (Grenier et al., 2003), enhance the virulence of the infectious agent (Failla, 2008) and decrease immune system function (Knutson and Wessling-Resnick, 2003).

Copper has a basic role in the metabolism and transition of Iron in the body. It is an essential component of several enzymes such as Ceruloplasmin, Cytochrome Coxidase, Lysil oxidase, Superoxid dismutase, and Tyrosinase, that are required to maintain host homeostasis (Swenson and Reece, 2004). Deficiency has been linked to a variety of clinical signs, including anemia, pale coat, spontaneous fractures, poor capillary integrity, myocardial degeneration, hypomyelinization of the spinal cord, impaired reproductive performance, and decreased resistance to infectious disease (Heidarpour Bami et al., 2008).

Appropriate trace mineral supplementation is essential for maintaining optimum level of growth and performance of the animal (Šrejberová et al., 2008).

The level of mastitis infection in a dairy herd has a significant impact on herd profitability. Losses due to mastitis include decreased milk production, increased treatment costs, discarded milk quality, premature culling, death, decreased genetic potential, decreased reproductive performance, load rejection due to violation of somatic cell counts (SCC) or antibiotic residues and loss of milk quality premiums (Oliver et el., 2000 and Ruegg and Reinemann 2002).

The objective of this study was to evaluate the effects of adding $\mathrm{Zn}, \mathrm{Cu}$ and $\mathrm{Se}$ in the ration of dairy cows on milk yield, SCC and blood parameters, as wall as milk quality and immune response in Friesian cows.

\section{MATERIALS AND METHODS}

The present study was carried out at Sakha Animal Production Research Station, belonging to the Animal Production Research Institute, Agricultural Research Center, Ministry of Agriculture and Land Reclamation, Egypt during the period from July to November 2010.

\section{Animals and management:}

A total of 39 healthy Friesian cows with an average of $532.7 \pm 23.5 \mathrm{~kg}$ body weight (BW), between 28 and 56 months of age and 1-3 parities were used in this study. All cows were chosen at late pre-partum period ( 8 months gestation). At the beginning of the experimental period, the experimental cows were divided into three similar groups, 13 in each. Mutiparous cows $(n=10$ in each group) were divided according to their BW, parity and milk production of the previous season, while primiparous cows ( $\mathrm{n}=3$ in each group) were allotted based only on their $\mathrm{BW}$.

Experimental cows were fed according to their BW and milk production. The $1^{\text {st }}$ group (G1) was served as a control. Cows of the $2^{\text {nd }}$ group (G2) were received $60 \mathrm{mg}$ $\mathrm{Zn}, 20 \mathrm{mg} \mathrm{Cu}$ and $0.3 \mathrm{mg} \mathrm{Se} / \mathrm{kg}$ diet at 30 day pre-partum to calving, while those of the $3^{\text {rd }}$ group (G3) were received the same dose of (G2) but on 1 to 60 days of postpartum in the ration. All cows were housed separately semi-open yards. 


\section{Feeding system:}

Experimental cows were fed a diet containing concentrate feed mixture (CFM), rice straw and corn silage according to the recommendation of NRC (2001) for dairy cows based on their live body weight and milk yield. The CFM was composed of $37.5 \%$ yellow corn, $20 \%$ soybean meal, $15 \%$ corn gluten, $22.5 \%$ wheat bran, $3 \%$ molasses, $0.5 \%$ and $1.5 \%$ common salt. Chemical analysis of representative monthly samples of foodstuffs was analyzed for CP, CF, EE, NFE and ash on DM basis according to the official methods of the A.O.A.C. (1995). Chemical composition of CFM, rice straw and corn silage as well as calculated chemical composition of the basal diet used in feeding cows in all groups is shown in Table (1).

Table 1. Chemical analysis of different feed stuffs (on dry matter basis) used in feeding cows in all groups

\begin{tabular}{|c|c|c|c|}
\hline \multirow{2}{*}{ Item } & \multicolumn{3}{|c|}{ Chemical composition (\%) } \\
\hline & CFM & Rice straw & Corn silage \\
\hline $\mathrm{DM}$ & 90.42 & 88.74 & 36.14 \\
\hline $\mathrm{OM}$ & 89.54 & 82.83 & 92.4 \\
\hline $\mathrm{CP}$ & 15.34 & 1.61 & 9.35 \\
\hline $\mathrm{CF}$ & 11.46 & 37.36 & 17.15 \\
\hline EE & 5.02 & 1.51 & 3.04 \\
\hline NFE & 57.72 & 42.35 & 56.8 \\
\hline Ash & 10.46 & 17.18 & 7.6 \\
\hline
\end{tabular}

\section{Experimental procedures:}

\section{Milk yield and composition:}

Cows were machine milked twice daily at 6:00 and 17:00 h. Daily milk yield (morning and evening) was individually recorded for the $1^{\text {st }}$ four months of lactation. Milk samples were biweekly collected to determine milk composition using MilkoScan (Model 133B). The 4\% fat corrected milk (4\% FCM) for each cow was calculated from milk yield according to the following formula:

$4 \% \mathrm{FCM}=$ Actual milk yield $(\mathrm{kg}) \times 0.4+15 \times$ fat yield $(\mathrm{kg})$ Geans equation, (cited by Abou-Raya, 1967).

\section{Somatic cell count (SCC):}

After bacteriological plating, SCC were determined for each milk sample with a Fossomatic 90 (A/S N Foss Electric, Hillerod, Denmark) between 24 and $48 \mathrm{~h}$ postcollection using the previously described method by (Gonzalo et al., 1993).

\section{Blood sampling:}

During the experimental period, blood samples were biweekly collected in clean test tubes via the jugular vein from all cows in each group. Blood plasma was separated by centrifugation of the collected blood at $15 \mathrm{~g}$ for $10 \mathrm{~min}$, and then plasma was kept frozen at $-20{ }^{\circ} \mathrm{C}$ until chemical analyses. Concentration of total proteins (Gornall et al., 1949) and albumin (Weichselaum, 1946) in blood plasma were determined using commercial kits (Diagnostic System Laboratories, Inc USA). Plasma globulin was calculated by subtracting concentration of albumin from total proteins. Plasma samples were analyzed for $\mathrm{Zn}, \mathrm{Cu}$ and Se by inductively coupled plasma-mass spectrometry. 
Statistical analysis:

The obtained data were statistically analyzed using SAS (1990). The significant differences among treatment groups were tested using Duncan's Multiple Range Test (Duncan, 1955). The statistical model was:

$Y_{i j}=U+A_{i}+e_{i j}$.

Where:

$Y_{i j}=$ Observed traits

$\mathrm{U}=$ Overall mean

$\mathrm{A}_{\mathrm{i}}=$ Experimental group 1-3 (1= G1, 2= G2 and 3=G3)

$\mathbf{e}_{\mathrm{ij}}=$ Random error

\section{RESULTS AND DISCUSSION}

Data in Table 2 show that pre-partum trace mineral supplementation of $\mathrm{Ze}, \mathrm{Cu}$ and $\mathrm{Se}(\mathrm{G} 2)$ increased $(\mathrm{P}<0.05)$ daily actual and fat corrected milk yield during the $1^{\text {st }}$ three months of lactation as compared to G1 (Table 2). However, the differences between $\mathrm{G} 1$ and $\mathrm{G} 3$ or $\mathrm{G} 2$ and G3 were not significant. Also, pre-partum trace mineral supplementation (G2) or post-partum periods (G3) improved fat, protein and lactose percentages as compared to $\mathrm{G} 1$, but the differences were only significant between G2 and G1, except protein was not significant. This may indicate that trace mineral supplementation during pre-partum has a positive reflection on the yield of fat and protein (Table 2). On the other hand, trace mineral supplementation reduced $(\mathrm{P}<0.05)$ somatic cell count in milk of $\mathrm{G} 2$ and $\mathrm{G} 3$ as compared to $\mathrm{G} 1$.

Table 2. Yield and composition of milk and somatic cell count as affected by trace mineral supplementation, throughout the first 120 days of lactation

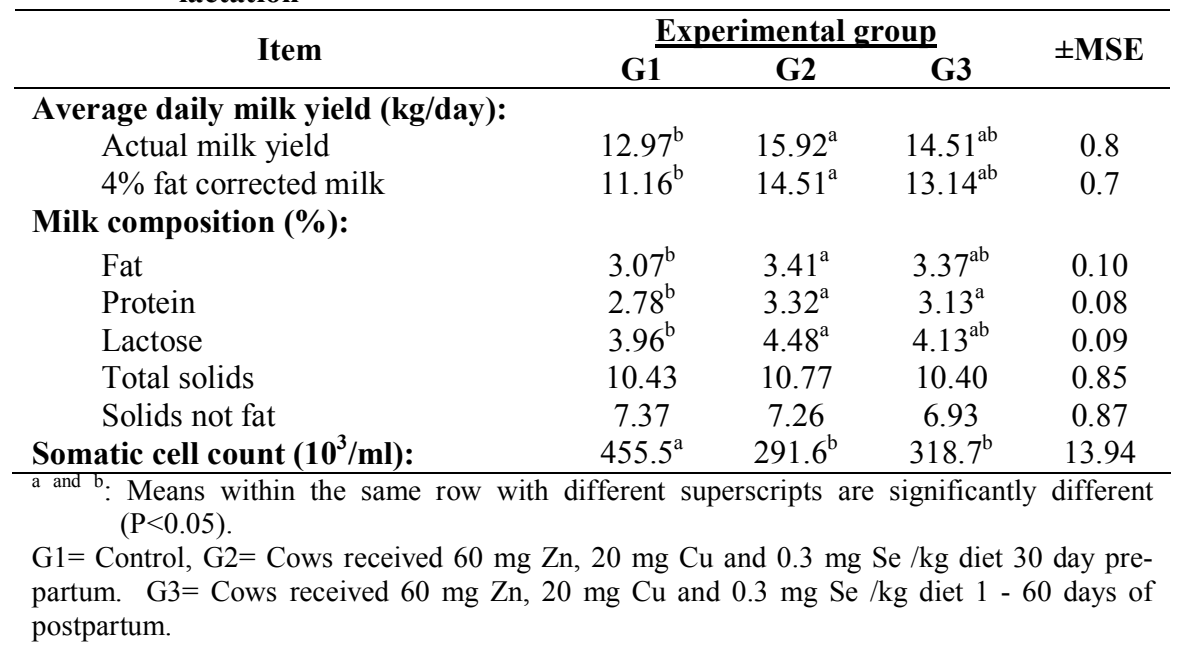

The present results come in line with the findings of Kincaid and Socha (2004), who reported an increase in milk yield between week 5 and 10 postpartum in highyielding dairy cows when supplemented with complexed minerals during postpartum. 
Moreover, these results are in agreement with Nocek et al. (2006), who reported an increased milk production in animals receiving diets containing complexed minerals and a mixture of inorganic minerals. In the studies of Nocek et al. (2006) using diet supplemented with a mixture of complexed minerals and supplemented in excess of NRC (2001) requirements, and do not permit the improvement in performance to be identified to one specific mineral. Other studies have observed that feeding organic minerals such as zinc methionine (Kellogg et al., 2004) can increase milk production. In contrast, Campbell et al. (1999) reported no effect on milk yield by feeding minerals in an organic form.

However, Neathery et al. (1973) reported no differences in milk composition when supplementing varying levels of $\mathrm{Zn}$ in the diet during postpartum, agreeing with the results from the current study. There was also no effect of $\mathrm{Zn}$ form on milk fat or protein, results agreeing with work carried out by Nocek et al. (2006). The concentration of $\mathrm{Zn}$ in milk is maintained over different concentrations of dietary $\mathrm{Zn}$ (Krebs, 1998). It is thought that this is because the mammary gland's import and export process of $\mathrm{Zn}$ has a strict regulation to maintain an adequate supply of $\mathrm{Zn}$ to the neonate (Kelleher and Lonnerdal, 2003).

Somatic cell count was decreased in cows treated with $\mathrm{Zn}, \mathrm{Cu}$ and $\mathrm{Se}$ than control group. There are a variety of trials that have demonstrated a link between selenium supplementation and udder health (Weiss, 2002). Malbe et al. (1995) demonstrated a reduction in somatic cell count when they supplemented selenium. Erskine et al (1989) showed that cows supplemented with $2 \mathrm{mg}$ of supplemental selenium per day showed greater resistance to mastitis compared to the control cows on a diet with $0.04 \mathrm{ppm}$ selenium. Kommisrud et al. (2005) concluded in their study on the association of blood selenium and health and fertility traits that there was a positive association between increased blood selenium concentration pre-partum and decreased incidence of mastitis. Whitaker et al. (1997) found a reduction in somatic cell count when zinc was supplemented in the region of $360 \mathrm{mg} / \mathrm{head} / \mathrm{day}$. Young et al. (1960) estimated the correlation of SCC and clinical mastitis to be 0.80 or 0.98 from two methods. The results agreed with (Harmon and Torre, 1997) who, supplemented selenium, zinc, and copper in dairy cattle diets and it has been shown to be important for improving udder health and reducing SCC in milk. Smith et al. (1985) found that supplemented heifers with subcutaneous injection of Se at 21 days prepartum showed 57\% reduction in clinical mastitis in early lactation and $32 \%$ reduction throughout lactation, and significantly lower somatic cell counts.

Data in Table (3) showed a significant $(\mathrm{P}<0.05)$ improvement of trace mineral supplemented diets on red blood cell (RBC) and white blood cell (WBC) counts, hemoglobin $(\mathrm{Hb})$ concentration and haematocrit percentage (HCT, \%) of cows. Treated cows showed higher haematological parameters than those in the control group. Such effect was maximized in G2, except for HCT (Table 3).

Similar results were obtained by Lominadze et al. (2004), who found that copper administration can cause significant increase in haemoglobin and serum copper levels.

Trace mineral supplementation $(\mathrm{Zn}, \mathrm{Cu}$ and $\mathrm{Se})$ significantly $(\mathrm{P}<0.05)$ improved immune response of treated cows. Treated cows showed significantly higher lymphocytes in $\mathrm{G} 3$ and significantly $(\mathrm{P}<0.05)$ reduced monocytes as compared to control group. Copper is an essential trace mineral which plays an important role in immune response of the animal. Both cell-mediated and humoral immunity were 
greatly reduced by copper deficiency (Solaiman et al., 2007). The supply of Zn improves performance, health, and immune function (Kellogg et al., 2004).

Table 3. Haematological parameters and immune response as affected by trace mineral supplementation, throughout the first 120 days of lactation

\begin{tabular}{|c|c|c|c|c|}
\hline \multirow{2}{*}{ Item } & \multicolumn{3}{|c|}{ Experimental groups } & \multirow{2}{*}{ \pm MSE } \\
\hline & G1 & G2 & G3 & \\
\hline \multicolumn{5}{|c|}{ Haematological parameters: } \\
\hline WBC $\quad\left(10^{3} / \mathrm{mm}^{3}\right)$ & $10.23^{\mathrm{b}}$ & $12.35^{\mathrm{a}}$ & $11.92^{\mathrm{a}}$ & 0.37 \\
\hline$(g / d L)$ & $9.54^{\mathrm{b}}$ & $10.68^{\mathrm{a}}$ & $10.43^{\mathrm{a}}$ & 0.23 \\
\hline$\left(10^{6} / \mathrm{mm}^{3}\right)$ & $6.11^{\mathrm{b}}$ & $7.12^{\mathrm{a}}$ & $6.79^{\mathrm{a}}$ & 0.22 \\
\hline Haematocrit (HCT, \%) & $28.3^{\mathrm{b}}$ & $30.42^{\mathrm{ab}}$ & $31.5^{\mathrm{a}}$ & 0.82 \\
\hline \multicolumn{5}{|l|}{ Immune response: } \\
\hline Lymphocytes (\%) & $66.56^{\mathrm{b}}$ & $67.22^{\mathrm{b}}$ & $72.05^{\mathrm{a}}$ & 1.64 \\
\hline Monocytes (\%) & $12.28^{\mathrm{a}}$ & $11.66^{\mathrm{a}}$ & $8.09^{\mathrm{b}}$ & 0.67 \\
\hline Granulocytes (\%) & 21.21 & 21.10 & 19.46 & 1.20 \\
\hline
\end{tabular}

${ }^{\mathrm{a} \text { and } \mathrm{b}}$ : Group means denoted with different superscripts are significantly different at $\mathrm{P}<0.05$.

Data in table (4) show a significant $(\mathrm{P}<0.05)$ effect of trace minerals supplemented $(\mathrm{Zn}, \mathrm{Cu}$ and $\mathrm{Se})$ pre-partum or postpartum on total protein, albumin and globulin and Se concentrations of cows blood plasma as compared to the control group. However, all parameters significantly higher in G3 than in G2, except plasma $\mathrm{Zn}$ and $\mathrm{Cu}$ concentration. The $\mathrm{Zn}$ is an essential trace mineral that is a constituent of enzymes involved in most metabolic pathways, and is important for protein metabolism, cell growth and repair, and immune function. The long-term effects of mild deficiency are unclear, but it has been suggested that they include delayed wound healing, suboptimal immune functioning, increased plasma lipid peroxides and perhaps reduced taste and smell acuity seen in the elderly (Fortes et al. 1997).

Table 4. Concentration of proteins, $\mathrm{Zn}, \mathrm{Cu}$ and $\mathrm{Se}$ in plasma as affected by trace mineral supplementation, throughout the first 120 days of lactation post-partum

\begin{tabular}{|c|c|c|c|c|}
\hline \multirow{2}{*}{ Item } & \multicolumn{3}{|c|}{ Experimental group } & \multirow{2}{*}{ \pm MSE } \\
\hline & G1 & G2 & G3 & \\
\hline Total protein $(\mathrm{g} / 100 \mathrm{ml})$ & $7.46^{\mathrm{c}}$ & $7.96^{b}$ & $8.28^{\mathrm{a}}$ & 0.03 \\
\hline Albumin $\quad(\mathrm{g} / 100 \mathrm{ml})$ & $3.34^{\mathrm{c}}$ & $3.68^{\mathrm{b}}$ & $3.90^{\mathrm{a}}$ & 0.02 \\
\hline$(\mathrm{g} / 100 \mathrm{ml})$ & $4.12^{\mathrm{c}}$ & $4.28^{\mathrm{b}}$ & $4.38^{\mathrm{a}}$ & 0.01 \\
\hline Plasma Zn & $14.3^{\mathrm{b}}$ & $15.6^{\mathrm{a}}$ & $15.3^{\mathrm{a}}$ & 0.32 \\
\hline Plasma Cu $(\mu \mathrm{mol} / \mathrm{L})$ & $16.3^{\mathrm{b}}$ & $17.8^{\mathrm{a}}$ & $17.4^{\mathrm{a}}$ & 0.27 \\
\hline Plasma Se $\quad(\mu \mathrm{mol} / \mathrm{L})$ & $0.86^{\mathrm{c}}$ & $0.97^{\mathrm{b}}$ & $1.12^{\mathrm{a}}$ & 0.01 \\
\hline
\end{tabular}

${ }^{\mathrm{a} \text { and } \mathrm{b}}$ : Group means denoted with different superscripts are significantly different at $\mathrm{P}<0.05$.

Appropriate trace mineral supplementation is essential for maintaining optimum level of growth and performance of the animal (Šrejberová et al., 2008).

Moreover, Se deficiency can adversely affect lymphocyte proliferative responses to mitogens in lambs (Turner et al., 1985), and Se supplementation of bovine lymphocytes enhanced IgM production in vitro (Stabel et al., 1991). 
Correlation coefficients between each of all milk parameters studied are presented in Table (5). Results show that SCC showed the strongest positive correlation with fat percentage $(\mathrm{r}=0.38501, \mathrm{P}<0.01)$ and negatively correlated with milk yield $(\mathrm{r}=0.17008, \mathrm{P}<0.05)$, lactose percentage $(\mathrm{r}=0.3845, \mathrm{P}<0.001)$.

Table 5. Pearson correlation coefficients between different milk parameters studied in both treated and control groups

\begin{tabular}{lcccccr}
\hline \multicolumn{1}{c}{ Item } & SCC & MY & Fat & Protein & Lactose & TS \\
\hline MY & $-0.17008^{*}$ & & & & & \\
Fat & $0.38501^{* *}$ & $-0.3613^{*}$ & & & & \\
Protein & $-0.0620^{\mathrm{NS}}$ & $0.0418^{\mathrm{NS}}$ & $-0.2279^{* * *}$ & & & \\
Lactose & $-0.3845^{* * *}$ & $-0.1266^{\mathrm{NS}}$ & $-0.35657^{* * *}$ & $0.16264^{*}$ & & \\
TS & $0.1168^{\mathrm{NS}}$ & $0.0823^{\mathrm{NS}}$ & $0.8581^{* * *}$ & $0.0799^{\mathrm{NS}}$ & $-0.1108^{\mathrm{NS}}$ & \\
SNF & $-0.1054^{\mathrm{NS}}$ & 0.04956 & $-0.12842^{\mathrm{NS}}$ & $0.5615^{* * *}$ & $0.4225^{* * *}$ & $0.399^{* * *}$ \\
\hline NS: Not significant, & * Significant at $\mathrm{P}<0.05$, & ** Significant at $\mathrm{P}<0.01$, & $* * *$ Significant \\
at P $<0.001$ & $\mathrm{MY}=$ milk yield.
\end{tabular}

It is of interest to note that the correlation was negative between fat and protein $(\mathrm{r}=0.2279, \mathrm{P}<0.001)$ and lactose percentage $(\mathrm{r}=0.35657, \mathrm{P}<0.001)$ and negative with TS $(0.8581, \mathrm{P}<0.001)$. The present results indicated a positive correlation between SCC and protein percentage, while SCC negatively correlated $(\mathrm{P}<0.05)$ with milk yield and $(\mathrm{P}<0.001)$ lactose percentage. The present results indicated positive correlation between protein and lactose percentages and between SNF and each of lactose and TS. Emanuelson (1988) found similar results since the correlations between SCC and milk yield were about the same magnitude as between clinical mastitis and milk production. In contrast to the results of this study, Emanuelson et al. (1988) found a genetic correlation between SCC and milk production.

\section{CONCLUSION}

The current study concluded that adding $\mathrm{Zn}, \mathrm{Cu}$ and $\mathrm{Se}$ at a level of $60 \mathrm{mg} \mathrm{Zn}, 20$ $\mathrm{mg} \mathrm{Cu}$ and $0.3 \mathrm{mg} \mathrm{Se} / \mathrm{kg}$ diet starting 30 days pre-partum improved $(22.5 \%)$ milk production and composition and decreased somatic cell count $\left(10^{3} / \mathrm{ml}\right)$, as wall as improved immune response of treated cows.

\section{REFERENCES}

A.O.A.C., 1995. Official Methods of Analysis, Association of Official Chemists, Washington, USA.

Bureau E., E. Gueux, A.M. Rock, I. Roussel, A. Mazur and Y. Rayssiguier, 2008. Female rats are protected against oxidative stress during copper deficiency. 11th International Symposium on Trace Elements in Man and Animals., P: 208E.

Campbell, M.H., J.K. Miller and F.N. Schrick, 1999. Effect of additional cobalt, copper, manganese, and zinc on reproduction and milk yield of lactating dairy cows receiving bovine somatrophin. J. Dairy Sci. 82:1019-1025.

Duncan D. B., 1955. Multiple rang and multiple F test. Biometrics 11: 1-42.

Emanuelson U., 1988. Recording of production diseases in cattle and possibilities for genetic improvements: a review. Livest. Prod. Sci. 20:89. 
Emanuelson U., B. Danell, and J. Philipsson, 1988. Genetic parameters for clinical mastitis, somatic cell counts, and milk production estimated by multiple-trait restricted maximum likelihood. J. Dairy Sci. 71:467.

Erskine, R.J., R.J. Eberhart, P.J. Grasso and R.W. Scholz, 1989. Induction of Escherichia coli mastitis in cows fed selenium-deficient or seleniumsupplemented diets. Am. J. Vet. Res. 50:2093.

Failla L., 2008. Trace Metals and Host Defense - Recent Advances and Continuing Challenges. $11^{\text {th }}$ International Symposium on Trace Elements in Man and Animals., pp: 204E.

Fortes C., N. Agabiti, V. Fano, R. Pacifici, F. Forastiere, F. Virgili, P. Zuccaro, C.A. Perruci and S. Ebrahim, 1997. Zinc supplementation and plasma lipid peroxides in an elderly population. European Journal of Clinical Nutrition 51, 97-101.

Gornall A. G., G. J. Bardawill, G. J. and M. M. Daved, 1949. J. Biol. Chem. 177: 751. C. F. Hartmann and Lascelles (1965)

Grenier, C., A. Heeren and O. Veado, 2003. Comparing zinc levels from Brazilian cattle tissues determined by ICP-MS with FAO's and USDA's Releases. J Nutr., 133: 217E-218E.

Harmon R.J. and P.M. Torre, 1997. Economic implications of copper and zinc proteinates: role in mastitis control. In: Biotechnology in the Feed Industry, Proceedings of the 13th Annual Symposium (T.P. Lyons and K.A. Jacques, eds). Nottingham University Press, Loughborough, Leics, UK. p. 419.

Heidarpour Bami, M., M. Mohri, H.A. Seifi, and A.A. AlaviTabatabaee, 2008. Effects of parenteral supply of iron and copper on hematology, weight gain, and health in neonatal dairy calves. Vet. Res. Comm., vol. 32, p. 553-561.

Kellogg D.W., D.J. Tomlinson and M.T. Socha, 2004. Effect of feeding zinc methionine complex on milk production and somatic cell count of dairy cattle: twelve-trial summary. Prof. Anim. Sci., 20, 295-301.

Kincaid, R. L. and M. T. Socha, 2004. Inorganic versus complexed trace mineral supplements on performance of dairy cows. The Professional Animal Scientist 20:66-73.

Knutson M. and M. Wessling-Resnick, 2003. Ferroportin-1 (Fpn1) and Iron Release by a Murine Macrophage Cell Line. J Nutr., 133: 206E.

Kommisrud E., O. Osteras and T. Vatn, 2005. Blood selenium associated with health and fertility in Norwegian dairy herds. Acta Vet. Scand.; 46(4): 229-40.

Lominadze D., J.T. Saari, S.S. Percival and D.A. Schuschke, 2004. Proinflammatory effects of copper deficiency on neutrophils and lung endothelial cells. Immunology and Cell Biology, 82, 231-238.

Malbe M., M. Klaassen, W. Fang, V. Myllys, M. Vikerpuur, K. Nyholm, W. Sankari, K. Suoranta, and M. Sandholm, 1995. Comparisons of selenite and selenium yeast feed supplements on Se-incorporation, mastitis, and leukocyte function in Sedeficient dairy cows. J. Vet. Med. (Ser. A) 42:111-121.

National Research Council. 2001. Nutrient Requirements of Dairy Cattle. Natl. Acad. Press, Washington DC.

National Research Council, 2001. Pages in Nutrient Requirements of Dairy Cattle. 7th rev. ed. Natl. Acad. Sci., Washington DC.

Neathery M.W., W.J. Miller, D.M. Blackmon and R.P. Gentry, 1973. Performance and milk zinc from low-zinc intake in Holstein cows. J. Dairy Sci., 56: 212-217. 
Nocek, J. E., M. T. Socha, and D. J. Tomlinson, 2006. The effect of trace mineral fortification level and source on performance of dairy cattle. J. Dairy Sci. 89:2679-2693.

Oliver S.P., F.N. Schrick, M.E. Hockett and H.H. Dowlen, 2000. Clinical and subclinical mastitis during early lactation impairs reproductive performance of dairy cows. Proc Regional Meeting of the National Mastitis Council, pp. 34-51.

Ruegg, P.L. and D.J. Reinemann, 2002. Milk quality and mastitis tests. University of Wisconsin Extension Service.

Smith K.L., H.R. Conrad, B.A. Amiet and D.A. Todhunter, 1985. Incidence of environmental mastitis as influenced by dietary vitamin $\mathrm{E}$ and selenium. Kieler Milchwirtschaftliche Forschungsberichte 37:482.

Solaiman S.G., T.J. Craig Jr., G. Reddy and C.E. Shoemaker, 2007. Effect of high levels of $\mathrm{Cu}$ supplement on growth performance, rumen fermentation, and immune responses in goat kids. Small Ruminant Research, 69,115-123.

Šrejberová P., M. Šoch and J. Brouček, 2008. Relationship between copper and zinc on selected haematological parameters in beef and dairy cattle. Slovak J. Anim. Sci., 41, 42-45.

Stabel J.R., T.A. Reinhardt, and B.J. Nonnecke, 1991. Effect of selenium and reducing agents on in vitro immunoglobulin $\mathrm{M}$ synthesis by bovine lymphocytes. Journal of Dairy Science 74, $2501-2506$.

Swenson M. J. and W.O. Reece, 2004. Duke's Physiology of Domestic Animals. Twelfth Edition, Cornell University, Press, Comstock Publishing Associates, Ithaca, New York, U.S.A. : William Reece (Editor), 1024 p. ISBN 978-0-80144238-4, 2004

Turner R. J., L.E. Wheaty, and F.G. Beck, 1985. Stimulatory effects of selenium on mitogen responses in lambs. Veterinary Immunology and Immunopathology 8, $119-124$.

Weichselaum T.E., 1946. Method for determination of albumin in serum blood. Amer. J. Clin. Pathol., 16: 40.

Weiss W.P., 2002. Relationship of mineral and vitamin supplementation with mastitis and milk quality. Proceedings National Mastitis Council Annual Meeting, pp37-44.

Whitaker D. A., H.F. Eayres, K. Aitchison and J.M. Kelly, 1997. No effect of a dietary zinc proteinate on clinical mastitis, infection rate, recovery rate, and somatic cell count in dairy cows. Vet. J. 153:197-204.

Young, C.W., J.E. Legates and J.G. Lecce, 1960. Genetic and phenotypic relationships between clinical mastitis, laboratory criteria, and udder height. J. Dairy Sci., 4354. 


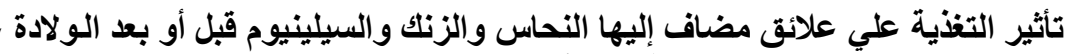
إنتاج اللبن وتعداد الخلايا الجسدية في الأبقار الفريزيان

\section{أحمد محمد أحمدٍِلامة، محمد عوض أبو الحمد، محمود سيا صياح، سمير علي إبراهيم}

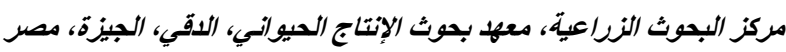

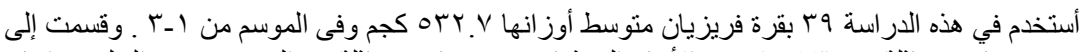

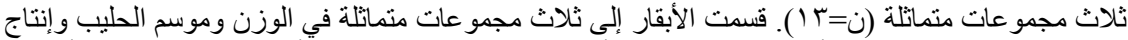

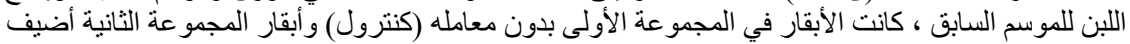

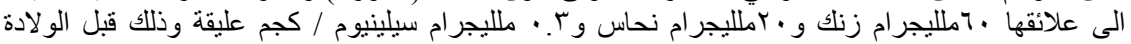

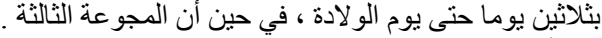

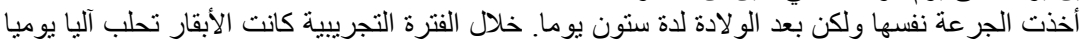

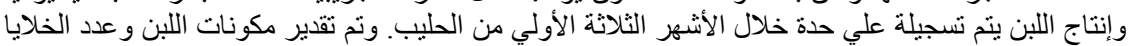

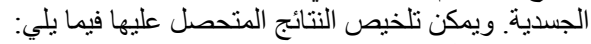

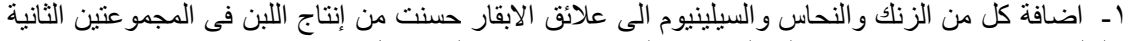

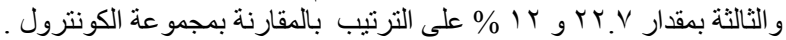

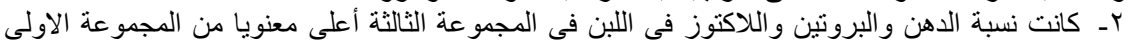

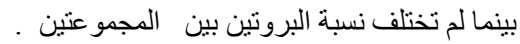

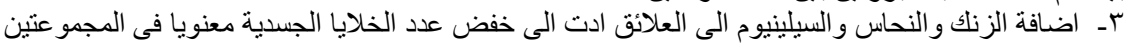

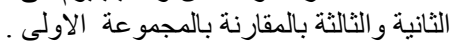

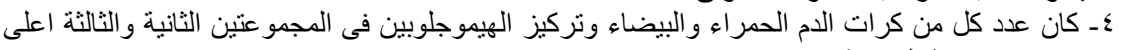
معنويا من مجمو عة المقارنة.

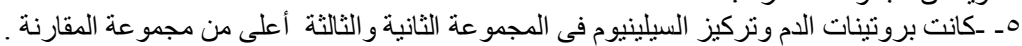

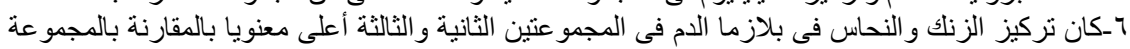
الاولى . 